\title{
Application of Pneumatically Actuated Dams in Urban River Regulation
}

\author{
Xiangyang Jing ${ }^{1, b}$ and Lian Liu ${ }^{2, a, ~ * ~}$ \\ ${ }^{1}$ PowerChina Chengdu Engineering Corporation Limited, Chengdu, 61000, China. \\ ${ }^{2}$ China Three Gorges University College of Hydraulic \& Environmental Engineering, Yichang, \\ 443002, China. \\ *, aliulian1986@hotmail.com, bxy_jing@126.com
}

\begin{abstract}
In the river of modern urban, water retaining dams should not only meet the regular functional requirements of flood control, water supply and shipping, but also coordinate with the urban environment and becomes an important part in construction of ecological water environment. This paper took a new type of water retaining dam-pneumatically actuated dam in Daxing river channel, Qinyi River, Sichuan Province as an example and elaborated its design procedure and functional characteristics in aspects of dam location selection, dam type selection, foundation treatment, reservoir seepage prevention and channel dredging respectively. By the comprehensive analysis, compared with the traditional concrete dams, the applications of pneumatically actuated dams have been one of the key means and development trend for river regulation engineering in modern urban.
\end{abstract}

Keywords: functional requirements; Sichuan Province; regulation engineering.

\section{Introduction}

The water conservancy engineering built in urban river should meet the material and culture demands of residents as well as the consistency with urban modernization [1]. Water retaining dam is one of the most common structures in urban river channels, whose main features are as follows [23]:

- The priority for the dam is flood control and drainage to guarantee the safety for residents.

- Low dam form with $2 \mathrm{~m}-5 \mathrm{~m}$ in water retaining height is adopted to keep water flowing gently.

- The compact, safe and economical layout of dam can meet the needs of urban water supply, cruise shipping, sediment and floating debris discharge and so on, although its space occupancy rate is relative low.

- It has the advantages of a good durability and simple operation and maintenance in later stage.

- The construction procedure is simple and time-saving, and the quantities of excavation and refilling are small.

It can be easily found that the traditional dam (the concrete gravity dam and the gate dam) is increasingly difficult to meet construction of the modern river channel due to their size with large space occupation, long construction period, large amount of excavation and less aesthetic appearance. Therefore, the new type of water retaining dam (the pneumatically actuated dam, the steel dam and the flexible dam) [4] will become mainstream dam types for river regulation engineering in modern urban.

\section{Present Situation on the Engineering}

Daxing river channel is located in Qingyi River, Sichuan Province, China, upstream and downstream in which Daxing Station and Shui jinguan Station are as shown in the Fig.1.The range of work is from the apron end of Daxing station to backwater end of Shui jinguan station, which extends about 3km.A flood protection levee is on left side bank and the tailwater channel of Daxing Station is on right. In addition, the built Daxing Bridge, the planned second Daxing Bridge ,Chengya Road on left bank and Yaxing Road on right all give a convenient transportation. 
The main problems in this channel included sedimentation, seepage of river bed and poor water quality. According to "Overall planning in Yaan City from 2013 to 2020", the intentions that it is essential to improve and upgrade the quality of living environment in central urban area by river ecological corridor construction were loudly proclaimed. Therefore, this engineering are focus on solving the cutoff problem from downstream of Daxing Dam to the end of tailwater channel to form a lake landscape and to further improve the human settlement in Yaan City.

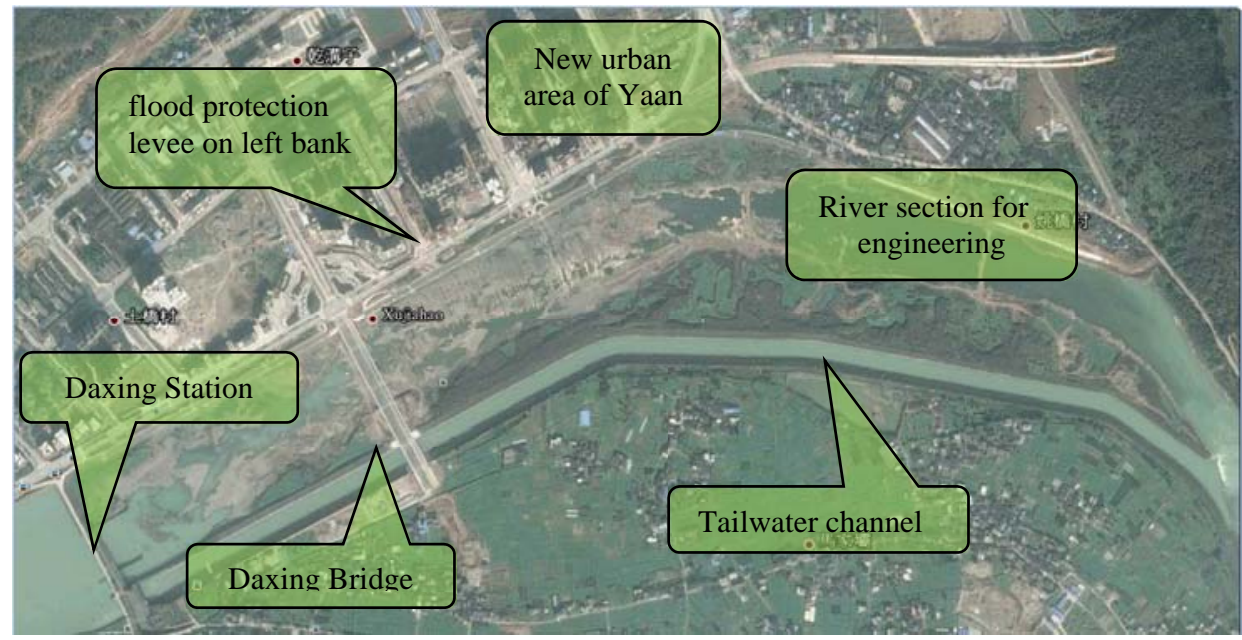

Figure 1. The Effect Diagram for a Completed Engineering

\section{General Layout of the Engineering}

According to the bottom elevation of the river bed, the shape of the river surface, the bridge location and landscape demand, a first grade dam was arranged near the center of wetland, where the reasonable joint of water levels of upstream and downstream should be taken into consideration, a large landscape in the wetland area should be guaranteed as well as the normal power generation of two stations. Besides, a second grade dam was set $700 \mathrm{~m}$ from the intersection between the main channel and tailwater channel of Daxing Station as shown in Figure 2.

The main buildings of first grade dam are joint dam section of left bank, pneumatically actuated dam section with 3 holes and joint dam section of right bank from left to right bank. Its normal water retaining level is $552.50 \mathrm{~m}$ and the storage capacity is $300000 \mathrm{~m} 3$; The crest elevation is $552.50 \mathrm{~m}$ and the crest length is $216.00 \mathrm{~m}$. The main buildings of second grade dam are joint dam section of left bank, pneumatically actuated dam section with 3 holes and joint dam section of right bank from left to right bank. Its normal water retaining level is $551.00 \mathrm{~m}$ and the storage capacity is $550000 \mathrm{~m} 3$; the crest elevation is $551.00 \mathrm{~m}$ and the crest length is $135.00 \mathrm{~m}$.

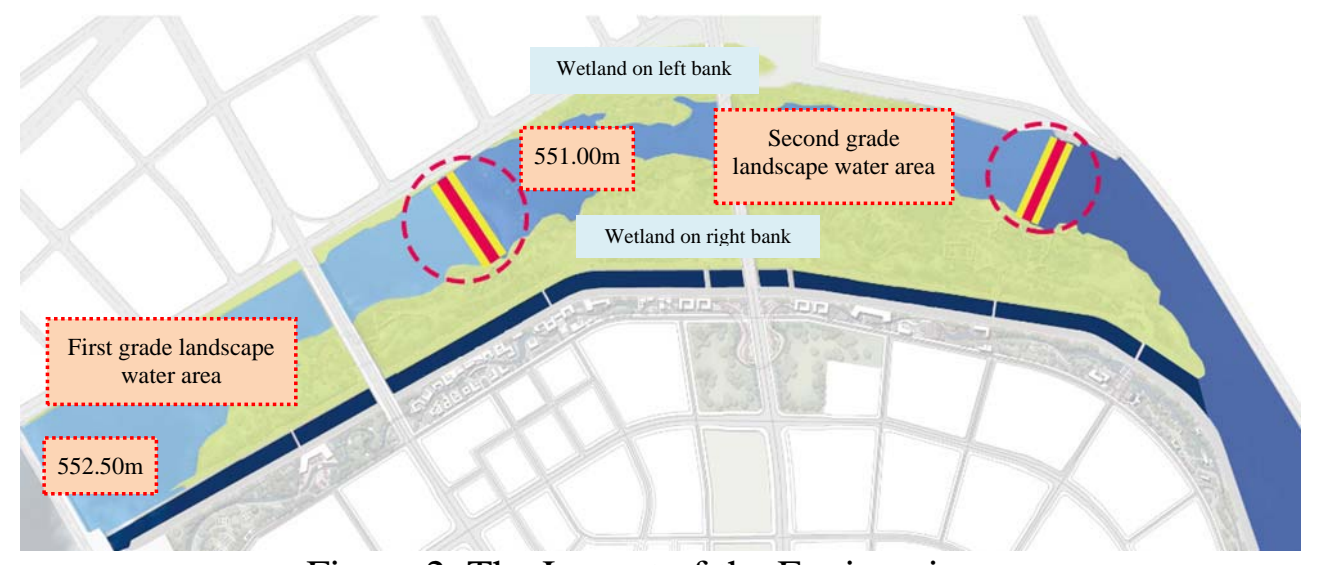

Figure 2. The Layout of the Engineering 


\section{Selection of Dam Types}

\subsection{Schemes of Pneumatically Actuated Dam Type}

Two types of dams, namely, the flexible dam and the steel dam, are selected to design their structures respectively.

\subsubsection{Scheme 1-the Flexible Dam}

- The first grade dam has 5 continuous dam bags filled with water, every bag is $2.50 \mathrm{~m}$ in height and $50.00 \mathrm{~m}$ in width; The foundation is $9.00 \mathrm{~m}$ in width and the crest length is $258.0 \mathrm{~m}$ The second grade dam has 3 continuous dam bags filled with water, every bag is $3.50 \mathrm{~m}$ in height and $55.00 \mathrm{~m}$ in width; The foundation is $13.50 \mathrm{~m}$ in width and the crest length is $170.00 \mathrm{~m}$. The crest elevations of two dams are both using the water level elevations.

- The structure of the dam bag is 3-layer cloth and 4-layer rubber anchored by pillow-style bolts. The reinforced concrete structure is applied in baseboard and the division pier of the dam. The thickness of baseboard is not less than $1 \mathrm{~m}$ and the embedding depth to bedrock is not less than $0.50 \mathrm{~m}$, it has a permanent seam every $10 \mathrm{~m}$. The thickness of the middle pier is $1.50 \mathrm{~m}$ and the side pier is $1 \mathrm{~m}$.

- The pump houses are set in left bank designed with double-deck masonry-concrete structure, the lower room of which is for power distribution and the upper one is for keeping watch .The area for a pump house is about $100 \mathrm{~m}^{2}$.

\subsubsection{Scheme 2-the Steel Dam}

- The first grade dam has 3-hole continuous steel dam, of which the water retaining level is $2.50 \mathrm{~m}$ and the width for each steel dam is $40.00 \mathrm{~m}$. The foundation was made of reinforced concrete and the width along the river of which is $6.20 \mathrm{~m}$, and the embedding depth to bedrock is not less than $0.50 \mathrm{~m}$.A hoist chamber is set between steel dams of which the width is range from $4.00 \mathrm{~m}$ to $5.80 \mathrm{~m}$ and the length along the river is $10.10 \mathrm{~m}$. The total length of the 3 -hole steel dam is $139.60 \mathrm{~m}$ (including hoist chamber).The length of spillway connected with the left bank is $60.00 \mathrm{~m}$, of which the maximum height is $5.90 \mathrm{~m}$ and the width of foundation along the river is $8.00 \mathrm{~m}$. The length of spillway connected with the right bank is $71.70 \mathrm{~m}$ with the maximum height of $3 \mathrm{~m}$, and the foundation is $8.00 \mathrm{~m}$ in width. The crest length of the first grade dam is $271.30 \mathrm{~m}$.

- The second grade dam has 3-hole continuous steel dam, of which the water retaining level is $3.00 \mathrm{~m}$ and the width for each steel dam is $40.00 \mathrm{~m}$. The foundation was made of reinforced concrete and the width along the river of which is $7.60 \mathrm{~m}$, and the embedding depth to bedrock is not less than $0.50 \mathrm{~m}$.A hoist chamber is set between steel dams of which the width is range from $4.80 \mathrm{~m}$ to $7.40 \mathrm{~m}$ and the length along the river is $12.60 \mathrm{~m}$. The total length of the 3-hole steel dam is $144.40 \mathrm{~m}$ (including hoist chamber). The length of spillway connected with the left bank is $10.00 \mathrm{~m}$, of which the maximum height is $7.00 \mathrm{~m}$ and the width of foundation along the river is $10.00 \mathrm{~m}$. The length of spillway connected with the right bank is $17.20 \mathrm{~m}$ with the maximum height of $7.00 \mathrm{~m}$, and the foundation is $10 \mathrm{~m}$ in width. The crest length of the first grade dam is $171.60 \mathrm{~m}$.

- The crest elevations of two dams are both using the water level elevations. The reinforced concrete structure is applied in baseboard of the dam and the embedding depth to bedrock is not less than $0.50 \mathrm{~m}$.

- Two distribution rooms are set in left bank of upstream and downstream power stations separately, which is double-deck masonry-concrete structure. The area for one is about $50 \mathrm{~m} 2$.

\subsection{Preliminary Scheme Comparison}

\subsubsection{The Flexible Dam}

\section{(1). Characters}

The flexible dam is generally built on the river with smooth flow, less sediment and floater ,as well as no bed load, with the characters of simple structure and low cost, while the material of dam bag has a tendency of deformation with poor durability and poor sturdiness. In addition, difficulties in maintenance are also the disadvantages of this type of dam. 
(2). Flood diversion capacity

When flood flows in river, the flood passing areas occupied by two dams in scheme 1 both are small, which account for less than $1 \%$ of the total area and have little effect on water level.

(3). Operation time

It generally take 2 hours to 3 hours to raising the flexible dam by filling water[5] .That means the flexible dam should be filled water regularly, otherwise it will collapse automatically.

(4). Service life

A high strength synthetic fiber is taken as a skeleton for the flexible dam, and the inside and outside both are coated with the rubber protective layer[6].The skeleton and protective layer form the dam bag that easily to be ruined by sharp objects, such as civilian facilities, building materials in flood discharge and blocks in debris flow. Furthermore, the vibration of dam, the frictions between dam and river bed as well as river banks are all damage the bags. The river section of this engineering with the high water head, the large flood discharge and the high sediment concentration in flood seasons, therefore, the scheme of flexible dam in this engineering condition will lead to increasing costs of later maintenance and deceasing of designed service life for bags. Additionally, it is possible that a few dam bags are completely destroyed during flood season due to the large amount of bed load in the engineering section. Generally, the service life of bags is 15 years, and in this engineering it is shorten to10 years considering a large amount of bed load of floater and sediment in Qingyi River.

(5). Operational reliability [7]

Air leak occurs commonly for the flexible dam due to cross-linking of rubber, punctures, pipe connection defects and fastening system and construction quality, so inflating bags constantly is needed to avoid their automatic collapse which affects normal function of water retaining. In such a situation, an air supply station or a pump house may be built nearby.

\subsubsection{The Steel Dam}

\section{(1). Characters}

The steel dam is a steel structure, of which the hydraulic driven gate is flexible in closing and opening, and it has the advantages of easy operation and time-saving gate scheduling. The hydraulic hoist chamber is a closed reinforced concrete structure with a high reliability in operation and a high abrasion resistance of steel plates which can meet the demand of flooding requirement of this engineering in flood seasons.

(2). Flood diversion capacity

When flood flows in river, the flood passing areas occupied by two dams in scheme 2 accounts for $1.0 \%$ and $5.6 \%$ of the total area separately. The height of banked-up water level from the first grade dam to Daxing Dam is from $0.05 \mathrm{~m}$ to $0.26 \mathrm{~m}$, and the one from the second grade dam to the first grade dam is from $0.24 \mathrm{~m}$ to $0.33 \mathrm{~m}$, which both have little effect on flooding areas.

(3). Operation time

The steel gate is opened and closed by the hoist, and its running speed can reach $1 \mathrm{~m}$ to $2 \mathrm{~m}$ per minute. Therefore, it takes no more than 2 minutes to complete the raising and lowering the dam for general works. Only in this way can it effectively ensure timely flood discharge when the outburst flood occurs.

(4). Service life

The design service life of the steel dam is up to 50 years to 60 years. The moving parts of steel gates are made of the special composites which do not need lubrication and rust protection for several years but one-time corrosion prevention in 30 years or so.

(5). Operational reliability

The steel dam needs to be equipped with two new type of driving devices. It is simple in structure and easy to operate without auxiliary facilities such as oil pipes and pumping stations. Besides, this driving device is equipped with a manual device. In case of power failure or other faults, manual operation can be carried out with the 5-kg operating force.

\subsubsection{Conclusions of Comprehensive Comparison}

A preliminary comparison between these two schemes is shown in Tab.1. 
Table 1. A preliminary Comparison between These Two Schemes

\begin{tabular}{cccccc}
\hline Scheme & $\begin{array}{c}\text { Flood diversion } \\
\text { capacity }\end{array}$ & $\begin{array}{c}\text { Sand } \\
\text { sluicing }\end{array}$ & $\begin{array}{c}\text { Service } \\
\text { life }\end{array}$ & $\begin{array}{c}\text { Direct cost } \\
\text { (10 thousand yuan) }\end{array}$ & Operation impact \\
\hline Flexible dam & Well-adapted & $\begin{array}{c}\text { Poor } \\
\text { abrasion } \\
\text { resistance }\end{array}$ & 10 years & 3523.86 & Long water filling time \\
Steel dam & Well-adapted & Well-adapted & 50 years & 3421.82 & $\begin{array}{c}\text { Artistic appearance, good } \\
\text { abrasion resistance }\end{array}$ \\
\hline
\end{tabular}

In summary, the investment of steel dam is relatively lower than that of rubber dam, considering the operation cost of 50 years. In addition, the river of high bed load and dirt in flood season will damage the flexible dam due to its poor abrasion resistance, while the steel dam is conducive to flood discharge and sand sluicing with the good abrasion resistance and the artistic appearance. Therefore, the steel dam is priority to the flexible dam in the preliminary comparison.

\subsection{Further Scheme Comparison}

Currently, there types of steel dams are applied commonly. They are separately the pneumatically actuated steel dam, the steel dam rotated on bed axes and the shutter dam.Tab. 2 compares the characteristics [8] of these three types of steel dams as follows.

Table 2. Comparison of Three Steel Dams

\begin{tabular}{|c|c|c|c|}
\hline Item & Pneumatically actuated steel dam & Steel dam rotated on bed axes ${ }^{[9]}$ & Shutter dam ${ }^{[10]}$ \\
\hline $\begin{array}{l}\text { Structure } \\
\text { diagram }\end{array}$ & Dam foundation & $\mathrm{C}_{\text {Golky }}$ & Facep ate \\
\hline $\begin{array}{l}\text { Flood diversion } \\
\text { capacity }\end{array}$ & $\begin{array}{l}\text { Drop it down to form an } \\
\text { arching(about } 35 \mathrm{~cm} \text { ) to overflow } \\
\text { well ,the inner spans is thin }\end{array}$ & $\begin{array}{l}\text { Drop it down to cling the river } \\
\text { bed(The bottom shaft extends out } \\
\text { of the river bed about } 27 \mathrm{~cm} \text { ) to } \\
\text { overflow well for a span.The inter } \\
\text { span pier size is larger due to the } \\
\text { layout of hydraulic hoist room }\end{array}$ & $\begin{array}{l}\text { Serious water blocking } \\
\text { problem. The piers take up } \\
\text { flooding areas. }\end{array}$ \\
\hline $\begin{array}{l}\text { Open-close } \\
\text { time }\end{array}$ & 20min-30min & $5 \mathrm{~min}$ & $\begin{array}{l}\text { The gate tends to be blocked by } \\
\text { the sundries to affect its } \\
\text { opening and closing }\end{array}$ \\
\hline $\begin{array}{l}\text { Flood discharge } \\
\text { in emergency }\end{array}$ & $\begin{array}{l}\text { Release manual air } \\
\text { on the bank }\end{array}$ & $\begin{array}{l}\text { Fill hydraulic fluid } \\
\text { in hoist chamber }\end{array}$ & No emergency operation \\
\hline $\begin{array}{l}\text { Warranty } \\
\text { period for } \\
\text { equipment }\end{array}$ & 20 years & 15 years-20 years & 15 years-20 years \\
\hline $\begin{array}{l}\text { Design service } \\
\text { life for } \\
\text { equipment }\end{array}$ & More than 50 years & More than 50 years & More than 40 years \\
\hline $\begin{array}{l}\text { Operation and } \\
\text { maintenance }\end{array}$ & $\begin{array}{c}\text { Regular inspections without air } \\
\text { supplement }\end{array}$ & $\begin{array}{l}\text { Regular inspections with hydraulic } \\
\text { fluid replacement }\end{array}$ & $\begin{array}{l}\text { Regular inspections of silt to } \\
\text { prevent gates from failing to } \\
\text { run }\end{array}$ \\
\hline Safety and risk & $\begin{array}{l}\text { High safety performance. Main risks } \\
\text { includes: quality of bags from } \\
\text { suppliers (layers ,materials, warranty } \\
\text { coverage and time) }\end{array}$ & $\begin{array}{l}\text { High safety performance. Main } \\
\text { risks includes: ventilation of } \\
\text { corridor and hoist room when they } \\
\text { operate, seepage prevention and } \\
\text { drainage, resistance to deformation } \\
\text { in seismic events }\end{array}$ & $\begin{array}{l}\text { The door opens automatically } \\
\text { by the balance effect between } \\
\text { water pressure and dead load. } \\
\text { Flood over-topping may lead to } \\
\text { an accident due to the } \\
\text { inaccurate control of opening } \\
\text { time of the gate. }\end{array}$ \\
\hline
\end{tabular}


In summary, the pneumatically actuated steel dam can well solves the problems of water storage, flood discharge and sediment accumulation in front the dam due to the disadvantages of simple structure, flooding without obstruction and easy sand flushing. Therefore, considering the high sediment in this river channel and operation experience of urban river landscape engineering in China, 3-hole pneumatically actuated steel dam is recommended to apply in the further scheme comparison.

\section{Design of Foundation Treatment}

The surface rocks of river bed are all intense weathered layer with low anti-eroding capability. Meanwhile, the designed flood standard for dam is comparatively low which leads to the high frequency of over-topping. Based on comprehensive analysis, the foundation of dam is placed in the moderate weathered layer. Since the excavation depth of the foundation is relatively shallow, there is no need for supporting treatment when the slope is excavated.

In order to improve the integrity of the dam foundation, the consolidation grouting is applied in foundation of two dams, of which the hole distance, the row distance as well as the hole depth are all $3 \mathrm{~m}$.

\section{Design of Seepage Prevention IN Reservoir Area}

\subsection{Foundation Seepage Prevention for Dams}

The foundation's components of the first and the second grade dams are mainly argillaceous siltstone, silty mudstone and grayish white marlite with low permeability. Additional, owing to the low dam height and the low hydraulic head, the seepage-prevention curtain is set up along the dam foundation.

\subsection{Seepage Prevention on Left Side of Daxing River Channel}

A protection embankment has been built on left side of Daxing river channel. In order to strengthen the seepage prevention, the filling materials between the original structural joints are removed, and then asphalt is painted $15 \mathrm{~m}$ away from the surface of structural joints in which the fir plates are installed, finally one layer of asphalt is added on the surface to prevent seepage.

\subsection{Seepage Prevention on Right Side of Daxing River Channel}

There are leakage passages on the right river bed of Daxing river channel in the first grated dam. To ensure the formation of water landscape, C25 concrete protection on the right bank slope above the river bed with the slope ratio of 1:1.35, and the foundation surface of the slope penetrates into the boundary of cover. The elevation of the slope prevention crest is $552.50 \mathrm{~m}$ and the embedded depth of slope toe is $0.80 \mathrm{~m}$. The cutoff wall of $240.00 \mathrm{~m}$ in length and $60.00 \mathrm{~m}$ in thickness cross through the leakage passages, which combines with the curtain grouting are set up below the foundation of concrete slope.

There are no leakage passages in the reservoir area of the second dam; therefore, the slope only requires to set up the seepage protection. Thereinto, the C25 concrete is used for slope protection with the slope ratio of 1:1.35.The foundation surface of the slope penetrates into the boundary of cover and the embedded depth of slope toe is $0.80 \mathrm{~m}$.

\section{River Channel Dredging}

The water level in this river channel is between $549.00 \mathrm{~m}$ to $552.50 \mathrm{~m}$, of which head difference is $3.50 \mathrm{~m}$.Based on the above analysis, the normal water levels for the first and the second grade dams are $552.50 \mathrm{~m}$ and $551.00 \mathrm{~m}$ respectively.

To restore the water ecological environment, a formation of a lake can effectively cover the flow reduced river channel. So a part of river bed sticking out above the water needs dredging. Furthermore, the areas whose shorelines are not smooth enough need the localized cleaning. The elevation for 
dredging in reservoir areas of the first and the second dams are $550.00 \mathrm{~m}$ and $548.00 \mathrm{~m}$ respectively. The quantities for dredging are about $116300 \mathrm{~m} 3$.

\section{Conclusion}

This engineering started in November 2016 and completed in March 2017.The effect diagram for a completed engineering is as shown in Fig.3.It aimed at this comprehensive control program as an ecological environment restoration in Qingyi River reach of Daxing District, Yaan City. Base on the comparison of the common steel dam types, the pneumatically actuated steel dam was approved to be applied in this engineering, and then other engineering measures besides the dam such as the slope prevention, the seepage prevention, dredging, etc. were designed and analyzed. Finally, the sedimentation and seepage problems in nearly 3-km river channel, as well as the water landscape recovering were well resolved. The period of this engineering was short. Since its completion, a good cultural environment was provided in Yaan City, and the value of land development along the Qingyi River was enhanced. In addition, more places of leisure and entertainment given to meet water loving need land to improve the quality of life for local people.

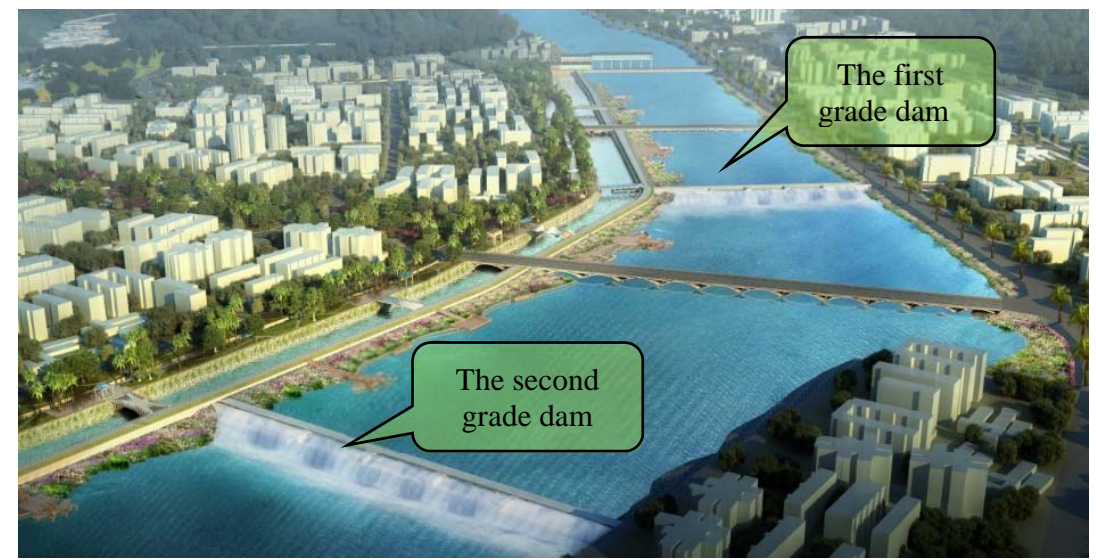

Figure 3. The Effect Diagram for a Completed Engineering

\section{Acknowledgments}

This work was supported by the Open Foundation of Key Laboratory of Changjiang River Scientific Research Institute of Changjiang Water Resources Commission (CKWV2016398/KY) and National Natural Science Foundation of China (SN: 51509143). The authors thank the reviewers for useful comments and suggestions that helped to improve the paper.

\section{References}

[1]. S. G. Xu, Planning and Construction of Modern Riverbank (China Water\&Power Press, Beijing, 2007), pp. 25-40.

[2]. Code for design of river regulation.GB50707-2011(China Planning Press, Beijing, 2011), pp. 24-27.

[3]. Code for design of urban flood control project.GB/T 50805-2012(China Planning Press, Beijing, 2011), pp. 32-35.

[4]. L. M. Chi, “Application of pneumatically actuated dams in Heihe river managing work of Changzhi City,” in Urban Road Bridges \& Flood Control, vol. 39, no. 12, pp.96-97(2016).

[5]. Y. Tian, "Experimental study on hydraulic characteristics of the water filled rubber dam," Master’s thesis, Taiyuan University of Technology, 2016. 
[6]. H.Chanson, “Use of rubber dams for flood mitigation in Hong Kong-Discussion,” in Journal of Irrigation and Drainage Engineering-asce, vol. 124, no. 3, pp.181-182(1998).

[7]. A. M. Binnie, “The theory of flexible dams inflated by water pressure,” in Journal of Hydraulic Research, no.3, pp.61-68(1973).

[8]. M. Z. Wei, “Analysis of static characteristics of pneumatic shield-shaped gate system,” Master’s thesis, Changchun Institute Technology, 2016.

[9]. L. Mu, “Advantages of steel dam in urban landscape construction”, in Water Conservancy Science and Technology and Economy, vol. 16, no. 10, pp.1195-1196(2010).

[10]. M. B.Charles, “Flap gate design for automatic upstream canal water level control”, in Journal of Irrigation and Drainage Engineer , vol. 127, no. 2, pp.84-91(2011). 